\title{
Abeta(1-42) induces abnormal alternative splicing of tau exons $2 / 3$ in NGF-induced PC12 cells
}

\author{
TERESA LAGUNES ${ }^{1}$, MARISOL HERRERA-RIVERO ${ }^{2 *}$, \\ MARÍA ELENA HERNÁNDEZ-AGUILAR ${ }^{3}$ and GONZALO E. ARANDA-ABREU ${ }^{3}$ \\ ${ }^{1}$ Centro de Investigaciones Cerebrales, Universidad Veracruzana, 91190, Xalapa, Veracruz, Mexico \\ ${ }^{2}$ Centro de Investigaciones Biomédicas, Universidad Veracruzana, 91190, Xalapa, Veracruz, Mexico \\ ${ }^{3}$ Cuerpo Académico de Neuroquímica, Centro de Investigaciones Cerebrales, \\ Universidad Veracruzana, 91190, Xalapa, Veracruz, Mexico
}

Manuscript received on August 16, 2013; accepted for publication on August 6, 2014

\begin{abstract}
Protein tau plays a pivotal role in the pathophysiology of Alzheimer's disease, where its hyperphosphorylation promotes aggregation and microtubule destabilization. Tau undergoes alternative splicing which generates six isoforms in the human brain, due to inclusion/exclusion of exons 2, 3 and 10 . Dysregulation of the splicing process of tau exon 10 is sufficient to cause tauopathy and has shown to be influenced by beta-amyloid peptides, but splicing of other exons is less studied. We studied the effects of beta-amyloid(42) in the alternative splicing of tau exons $2 / 3$ and 6 , using untreated and Nerve Growth Factor-induced PC12 cells. Beta-amyloid exposure caused formed cell processes to retract in differentiated cells and altered the expression of exons $2 / 3$ in both undifferentiated and differentiated cells. Expression of exon 6 was repressed in undifferentiated cells only. Our results suggest that beta-amyloid interferes with the splicing process of exons $2 / 3$, favoring their exclusion and thus the expression of immature tau isoforms that are less efficient in stabilizing microtubules and may also be more prone to hyperphosphorylation. The molecular mechanism for this amyloid-tau interaction remains to be determined, but may have potential implications for the understanding of the underlying neuropathological processes in Alzheimer's disease.
\end{abstract}

Key words: Alzheimer's disease, amyloid peptide, splicing regulation, tau isoforms.

\section{INTRODUCTION}

Protein tau is involved in microtubule assembly and stabilization; hence the name microtubuleassociated protein tau (MAPT) (Weingarten et al. 1975). Nevertheless, tau localization and functions are not limited to microtubules. Microtubule-

Correspondence to: Gonzalo Emiliano Aranda-Abreu

E-mail: garanda@uv.mx

* Doctorado en Ciencias Biomédicas binding domains are located at the $\mathrm{C}$-terminus (CT) of the protein while the N-terminus (NT) appears to regulate its localization. Membrane associations of tau have been studied in PC12 cells overexpressing tau and its fragments, where the NTF proved to have a role in neuritic development and microtubuleplasma membrane interactions (Brandt et al. 1995).

Hyperphosphorylation of MAPT in the human brain has for a long time, been known to contribute 
to Alzheimer's disease (AD) pathology by tau disassociation from microtubules to aggregate and form neurofibrillary tangles (NFTs), but the phosphorylation state at the serine/threonine residues seems to also be a regulator of tau intracellular trafficking; membrane-associated tau shows dephosphorylation at these sites, which probably increases its association with trafficking proteins that target tau to the plasma membrane. Tau hyperphosphorylation in AD thus, may play yet another role in the pathology by disrupting targeting to the plasma membrane, ultimately inhibiting the protein's functions there (Pooler and Hanger 2010).

Six tau isoforms ranging from 352 to 441 amino acid residues are found in the human brain (Goedert and Jakes 1990) as a result of the alternative splicing of exons 2, 3 and 10 (Figure 1) (Andreadis et al.
1992). The inclusion of exons 2 and 3 produces isoforms with 0,1 or 2 insertions near the NTF $(0 \mathrm{~N}-$, $1 \mathrm{~N}-, 2 \mathrm{~N}-\mathrm{tau}$ ) of the tau protein (Andreadis et al. 1992, D'Souza and Schellenberg 2005). Exon 3 never appears independent from exon 2 and is regulated by a weak branch point and a combination of exonic enhancers and silencers (Arikan et al. 2002). Exon 6 seems to be regulated by flanking exons that participate in its inclusion and the modulation of variant ratios (Wei and Andreadis 1998). Exon 10 is a repeat region for microtubule binding (Goedert et al. 1989); its alternative splicing produces almost equally expressing isoforms containing either three (3R-tau without exon 10) or four (4R-tau with exon 10) microtubule-binding domains. Dysregulation of exon 10 alternative splicing has shown to be sufficient to cause neurodegeneration (Liu and Gong 2008).

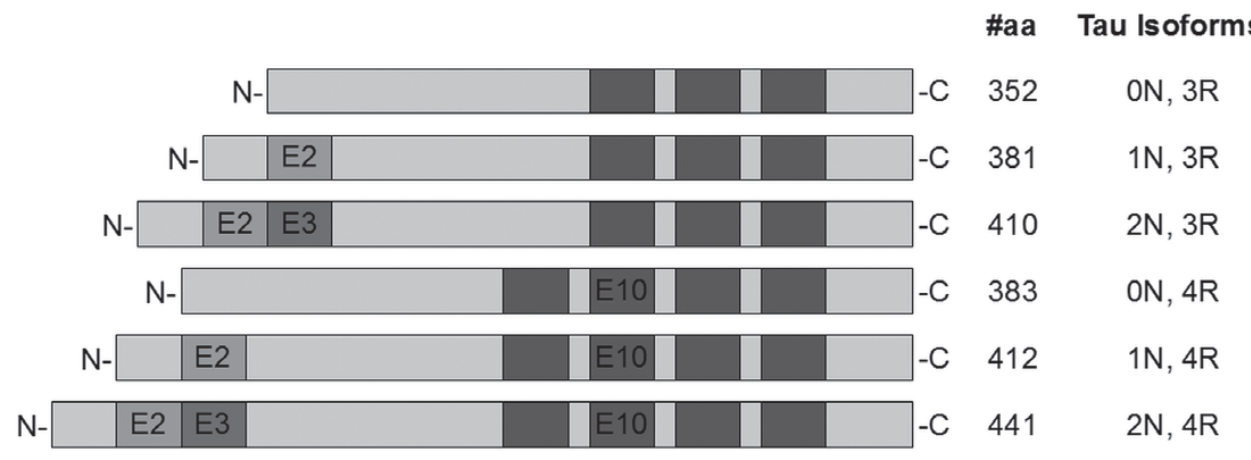

Figure 1 - Representation of the six tau isoforms generated in the human brain from the alternative splicing of exons 2, 3 and 10.

Tauopathy is present in $\mathrm{AD}$ as a hallmark feature, along with beta-amyloid $(\mathrm{A} \beta)$ pathology. The discovery of the interactions between $A \beta$ and tau has implications for the development of strategies that could possibly help prevent neurodegeneration (Chen et al. 2010). We hypothesized that $\mathrm{A} \beta_{42}$ exposure can induce alterations in the alternative splicing of tau exons 2, 3 and/or 6; to address this, we studied the expression of regions comprising exons 1 to 9 and their possible $\mathrm{A} \beta$-induced alterations, using undifferentiated and differentiated neuron-like PC12 cells induced by nerve-growth factor (NGF) (Greene and Tischler 1976).

\section{MATERIALS AND METHODS}

PC12 Cell Cultures and AB A $_{42}$ Peptide Exposure

PC12 cells were placed in 85\% RPMI 1640 culture medium (GIBCO) supplemented with 5\% fetal bovine serum, $10 \%$ horse serum and $50 \mu \mathrm{l} / \mathrm{ml}$ liquid penicillin-streptomycin (GIBCO, SKU\# 15140122). 2,500 cells $/ \mathrm{ml}$ per well were seeded in PolyD-Lysine coated 96-well plates and incubated at $37^{\circ} \mathrm{C}$ with $5 \% \mathrm{CO}_{2}$ atmosphere. A) Undifferentiated PC12 cells were either incubated with $2 \mu \mathrm{M} \mathrm{A} \beta_{42}$ or without $\mathrm{A} \beta$ as controls for a $24 \mathrm{~h}$ period. $\mathrm{B}$ ) 
Differentiation was induced by the addition of 50ng/ml NGF-7S (Sigma, SKU\# N0513) to the culture medium. Cells were initially incubated for a period of $24 \mathrm{~h}$, after which medium was changed for 1\% RPMI 1640 supplemented with horse serum. $10 \mu \mathrm{l}$ of $50 \mu \mathrm{M}$ NGF-7s were added to the medium every $24 \mathrm{~h}$ for up to $96 \mathrm{~h}$ and then, either $2 \mu \mathrm{M} \mathrm{A} \beta_{42}$ or no $A \beta$ (for controls) was added for a final $24 \mathrm{~h}$ incubation period.

\section{Cell Morphology}

Morphological changes in PC12 cells due to NGFinduced differentiation and $\mathrm{A} \beta_{42}$ treatment were visualized using a professional binocular inverted microscope (Zeigen, Mexico) and photographed with the complementary digital camera and software provided by the microscope's manufacturer. Images were obtained with the 40x objective, condenser ELWD N.A. 0.35, plan-achromatic objective PL20/0.35.

\section{EXPRESSION ANALYSIS OF TAU EXONS BY RT-PCR}

Total RNA from PC12 cells was isolated by the Trizol (Invitrogen) method, following manufacturer's instructions; after quantification and integrity assessment, the RNA was stored at $-80^{\circ} \mathrm{C}$ until further utilization. Expression of tau exons 1 to 9 was analyzed by RT-PCR. Retro-transcription was performed with $1 \mu \mathrm{g}$ total RNA using moloney murine leukemia virus reverse transcriptase, M-MLV RT
(Invitrogen, SKU\# 28025-021), by addition of $1 \mu 1$ oligo $(\mathrm{dT})_{12-18}(500 \mu \mathrm{g} / \mathrm{ml}), 1 \mu \mathrm{l} \mathrm{dNTPs} \operatorname{mix}(10 \mathrm{mM})$ and sterile distilled water to a volume of $12 \mu 1$ to the RNA, to heat at $70^{\circ} \mathrm{C}$ for 3 minutes and quickly chill on ice, followed by addition of $5 \mu \mathrm{l} 5 \mathrm{X}$ first-strand buffer, $2 \mu \mathrm{LTT}(0.1 \mathrm{M})$ and $1 \mu \mathrm{M}$ M-MLV to incubate at $37^{\circ} \mathrm{C}$ for $1 \mathrm{~h}$ and inactivate the reaction at $94^{\circ} \mathrm{C}$ for 5 minutes. Amplification of cDNA fragments of regions comprising exons 1 to 5,5 to 9,7 to 9 and 6, as well as glyceraldehyde 3-phosphate dehydrogenase (GAPDH) as housekeeping gene, was performed with $2 \mu 1$ of the synthetized cDNA plus $1 \mu 1$ of each (forward/reverse) primer $(50 \mu \mathrm{M}), 5 \mu \mathrm{l} 10 \mathrm{X}$ PCR buffer, $1 \mu 1 \mathrm{dNTPs}$ mix, $5 \mu 1 \mathrm{MgCl}_{2}(50 \mathrm{mM}), 0.5 \mu 1$ Taq DNA polymerase $(5 \mathrm{U} / \mu \mathrm{l})$ and sterile distilled water to a final volume of $50 \mu \mathrm{l}$, under the following PCR conditions: hot start at $94^{\circ} \mathrm{C}$ for 2 minutes, 35 cycles of denaturalization at $94^{\circ} \mathrm{C}$ for 1 minute, annealing at $63^{\circ} \mathrm{C}$ for 1 minute and elongation at $72^{\circ} \mathrm{C}$ for 1 minute, with a final extension at $72^{\circ} \mathrm{C}$ for 5 minutes. Primer sequences and expected PCR products are found in Table I (Vanier et al. 1998). All reagents used for the RT-PCR reactions were from Invitrogen.

\section{RESULTS}

Morphological changes in NGF-induced PC12 cells were observed as a result of $\mathrm{A} \beta_{42}$ peptide exposure (Figure 2): 30 min after peptide addition

TABLE I

PCR pairs of primer sequences and expected product sizes (Vanier et al. 1998).

\begin{tabular}{ccccc}
\hline Name & Sense & Sequence & Fragment (bp) & Exons \\
\hline Ex1 & Forward & 5'-CGCCAGGAGTTTGACACAATGG-3' & Fetal: 189 & $\begin{array}{c}1+4+5 \\
\text { Adult: } 280\end{array}$ \\
EX5A & Reverse & 5'-TCCTGTCCTGTCTTTGCTTACG-3' & 363 & $1+2+3+4+5$ \\
\hline EX5 & Forward & 5'-CGAGTGGCCGGCGTAAGCAAA-3' & 393 & $5+7+9$ \\
EX9 & Reverse & 5'-CTTTAGGTCTGGCATGGGCAC-3' & 591 & $5+6+7+9$ \\
\hline EX7 & Forward & 5'-GCCAGAAAGGCACATCCAATGC-3' & \multirow{2}{*}{281} & $7+9$ \\
EX9 & Reverse & 5'-CTTTAGGTCTGGCATGGGCAC-3' & & 6 \\
\hline EX6S & Forward & 5'-AGAAAGCCAAGACATCCACAC-3' & 214 & \\
EX6AS & Reverse & 5'-GCGCCCTTGAGTTTCATCTG-3' & & \\
\hline GAPDH & Forward & 5'-GCCATCAACGACCCCTTCAT-3' & 314 & \\
& Reverse & 5'-TTCACACCCATCACAAACAT-3' & & \\
\hline
\end{tabular}



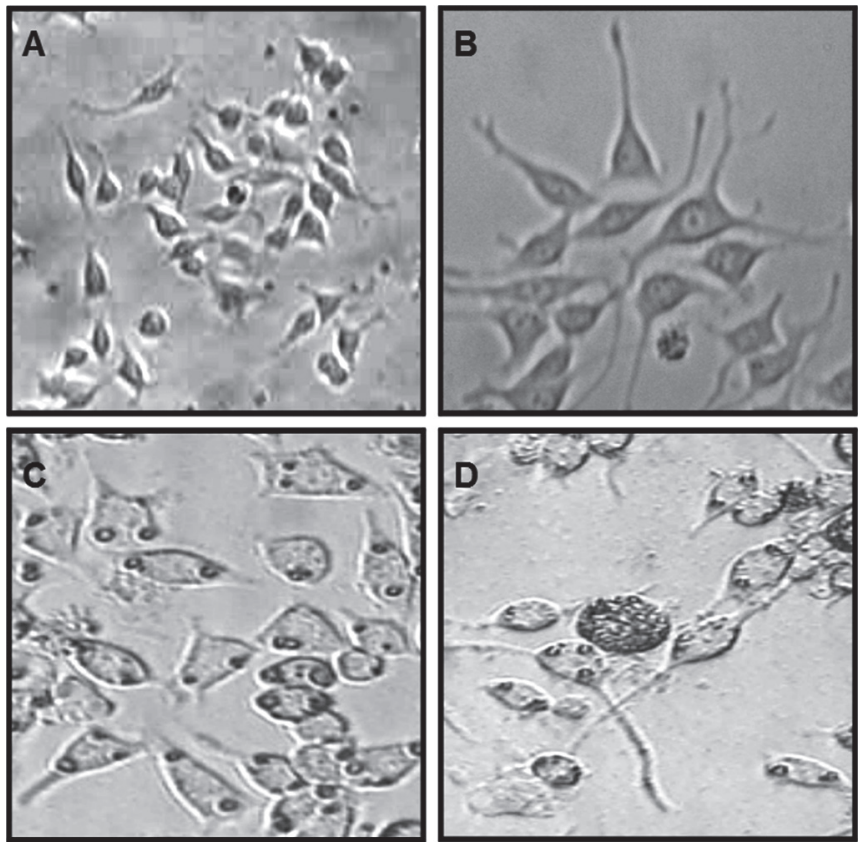

Figure 2 - A $\beta$-induced morphological changes in PC12 cells. Untreated A) undifferentiated and B) NGF-induced cells; differentiated cells after C) $30 \mathrm{~min}$ and D) $24 \mathrm{~h}$ of $A \beta$ exposure. $A \beta$ treatment causes the appearance of inclusions and neurite retraction. Inverted microscope. Magnification: 40X.

to the culture medium, the neuron-like cells started showing inclusions that were followed by retraction of their processes after $24 \mathrm{~h}$.

To investigate the effects of $A \beta_{42}$ in the alternative splicing of tau exons 2, 3 and 6 , we analyzed their expression by RT-PCR in untreated undifferentiated and differentiated $\mathrm{PC} 12$ cells, in order to establish a control, and in $\mathrm{A} \beta$-treated undifferentiated and differentiated cells. As shown in Figure 3, we first observed a visible decrease in the expression levels of all fragments amplified in cells that were treated with $A \beta_{42}$ peptide, compared to controls. Undifferentiated and NGF-induced cells showed a very similar expression pattern of all amplified fragments when cells were not treated with the $\mathrm{A} \beta_{42}$ peptide; nevertheless, when $\mathrm{A} \beta_{42}$ was added to cell cultures, we observed a couple of differences between undifferentiated and differentiated cells.

Expression of exons 2 and 3 was investigated using the primer pair Ex1/Ex5A. All three bands found in the adult brain by Vanier were found in untreated undifferentiated cells, with fragment $189 \mathrm{bp}$ corresponding to exons $1+4+5$, fragment $280 \mathrm{bp}$ to exons $1+2+4+5$ and fragment $363 \mathrm{bp}$ to exons $1+2+3+4+5$, from which fragment $363 \mathrm{bp}$ appears to express in a slightly higher level than the others (Figure 3A); fragment 189bp, which corresponds to fetal tau, was not however, detected in differentiated PC12 cells (Figure 3B). When cells were exposed to the $A \beta_{42}$ peptide, exons 2 and 3 were not expressed in either undifferentiated (Figure 3C) or differentiated (Figure 3D) cells, as observed by the amplification of only one band corresponding to fetal tau (189bp fragment). Inclusion of exon 6 was investigated by the use of two primer pairs: Ex5/Ex9 and the exon specific Ex6S/Ex6AS. In undifferentiated A $\beta$-treated cells, exon 6 amplification with the primer pair Ex6S/ Ex6AS showed no expression of this region, and the region amplified with the primer pair Ex5/Ex9 


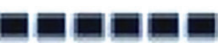

$\begin{array}{llllll}1 & 2 & 3 & 4 & 4 \mathrm{~A} & 5\end{array}$

Tau exons $1-5 \mathrm{~A}$

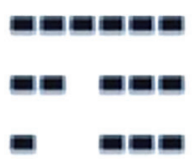

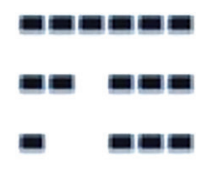

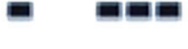

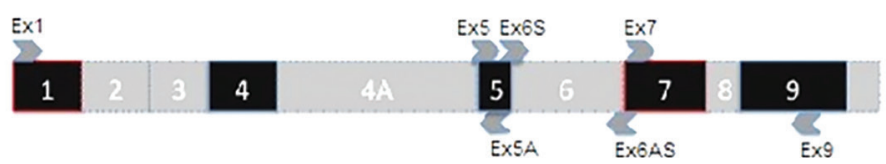

Constitutive exon
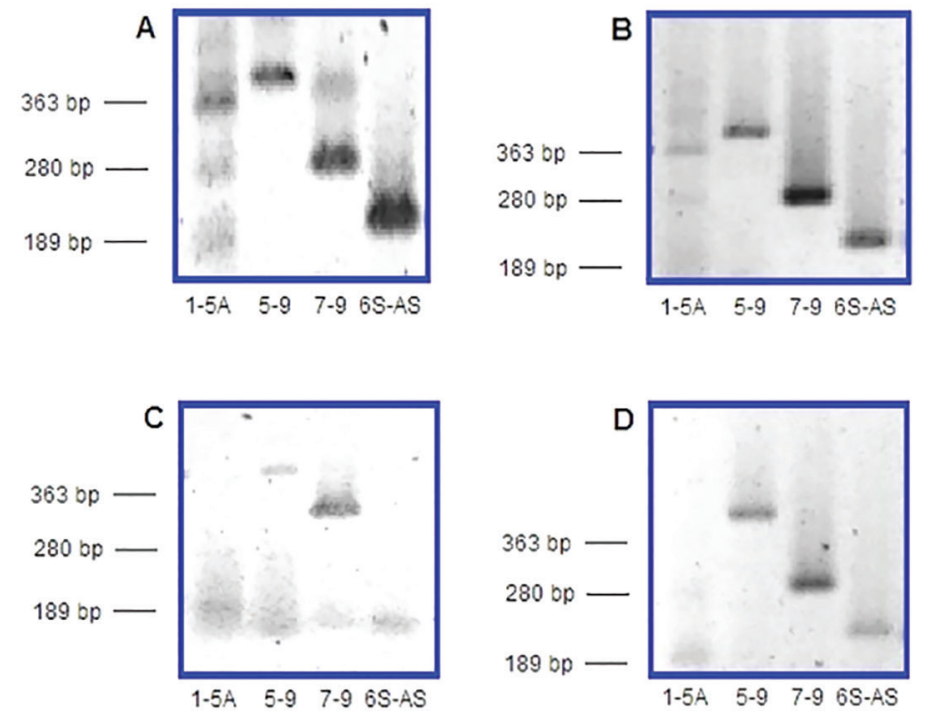

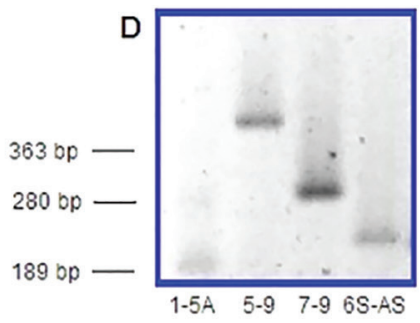

Figure 3 - Representations of protein tau, exons 1 to 9 (modified from Vanier et al. 1998) and the exons 1 to 5 comprised in the region amplified by primer pair Ex1/Ex5A. Expression of tau exons 2/3 (Ex1/Ex5A), 6 (Ex5/Ex9, Ex6S/Ex6AS) and 8 (Ex7/Ex9) from: untreated A) undifferentiated and B) NGF-induced differentiated PC12 cells; and from PC12 cells exposed to $\mathrm{A} \beta_{(1-42)}$ peptide in C) undifferentiated and D) NGF-induced differentiated cells. Differentiation inhibits fetal tau expression. $\mathrm{A} \beta$ exposure promotes exclusion of exons $2 / 3$ in undifferentiated and differentiated cells, and exclusion of exon 6 in undifferentiated cells.

appeared to express in a lower level, compared to differentiated cells. Untreated and $A \beta$-treated differentiated cells showed expression using the exon 6 specific primer pair and only one band of $393 \mathrm{bp}$ using the non-specific primers. Regarding the expression of exons 7-9, they remain unchanged in their expression, during treatment.

\section{DISCUSSION}

In this study, we demonstrated that $\mathrm{A} \beta_{42}$ peptide exposure causes morphological changes and alters the splicing process of tau exons 2 and 3 in PC12 cells, favoring non-inclusion of both exons (i.e. expression of fetal tau). The study of tau alternative splicing and the effects $A \beta_{42}$ peptide can exert on this process, may help to better understand the origin of tau pathology in AD. The splicing of exon 10, which generates tau spliced variants with 3 or 4 microtubule-binding domains, has been widely studied and it has already been demonstrated that alterations in this process can cause neurodegeneration. Dyrk1A-SC35 (Qian et al. 2011), Dyrk1A-9G8 (Ding et al. 2012) and (PKA-C $\alpha$ )-SRSF1 (Shi et al. 2011) interactions contribute to neurodegeneration in the $\mathrm{AD}$ brain by altering regulation of tau exon 10 splicing through phosphorylation. In addition, a fairly recent study has provided some insights into the 
$\mathrm{A} \beta$-tau relationship demonstrating that $\mathrm{A} \beta$ can alter the splicing of tau exon 10 and cause imbalanced expression of 3R/4R-tau through $A \beta-(G S K-3 \beta)$ SC35 (Chen et al. 2010) interactions.

Similar abnormalities in the alternative splicing of exons 2,3 and 6 may also induce tau pathology in AD as a response to $A \beta$ aggregation. Mature tau isoforms have demonstrated to participate in the stabilization of neurites when inducing PC12 cell differentiation using NGF (Hanemaaijer and Ginzburg 1991). This suggests that inclusion of MAPT exons 2 and 3 promotes switching from immature to mature tau isoforms that stabilize microtubules. Here, we observed these mature isoforms by analyzing inclusion of exons 2 and 3, and showed $1 \mathrm{~N}$ - and $2 \mathrm{~N}$-tau were expressed in undifferentiated as well as differentiated PC12 cells but, when we exposed these cells to $A \beta_{42}$ peptide, only the immature $0 \mathrm{~N}$-tau isoform (fetal tau) was expressed, even in differentiated cells. These results suggest that $A \beta$ peptides may be altering the alternative splicing of tau in the $\mathrm{AD}$ brain, promoting the exclusion of exons 2 and 3 and generating immature tau isoforms that make microtubules unstable. Furthermore, fetal tau, similar to the tau found in the NFTs in AD, has shown to be hyperphosphorylated (Smith et al. 1995). Thus, an A $\beta$-induced exclusion of exons 2 and 3 in AD may destabilize neurites by altering both regulatory mechanisms involving tau: isoforms and phosphorylation.

Exon 6 is contained in high molecular weight tau, but not in the low molecular weight tau found in the human and rat brains; however, exon 6 inclusion has been reported in AR42J tumoral pancreatic acinar cells, using the primer pair Ex5/ Ex9, as a second amplified fragment of 591bp to the expected 393bp fragment lacking of exon 6 (Vanier et al. 1998). In our study, we did not find a 591 bp fragment, even when exon 6 expression was observed by amplification with the exon specific primer pair Ex6S/Ex6AS. Although we are unaware unclear for this finding, amplification with exon 6 specific primers showing a high level of expression of the corresponding 214bp fragment in untreated cells is undeniable. We believe inclusion of this exon may be due to the cell line used in this study, as it could be a feature shared by several (or all) tumoral cells; in addition, the inclusion of exon 6 in the longest adult tau isoform has been reported to inhibit neurite elongation in neuroblastoma cells (Luo et al. 2004). These observations open the possibility for this particular long tau species to be constitutively expressed in PC12 cells and decrease its expression upon NGF treatment, when the formation and elongation of cellular processes is induced. Nevertheless, $A \beta_{42}$ exposure affects exon 6 splicing regulation, promoting exclusion in undifferentiated cells and inclusion in differentiated cells, but without promoting expression of the long adult tau isoform also including exons 2 and 3 .

It has been shown that the timing and expression pattern of tau alternative splicing is independent of neuronal connectivity and/or environmental signaling (Collet et al. 1997); however, mRNA expression and splicing have recently proven to vary in a region-dependent manner in the human brain (Trabzuni et al. 2012), for which we do not wish to draw any strong conclusions from our results. Nonetheless, even though further study of these observations is required, especially using an AD model, and the specific molecular interactions between $A \beta_{42}$ and the splicing regulation of tau exons 2, 3 and 6 remain to be determined, our results contribute to increasing the evidence to establish interactions between amyloid and tau pathologies in $\mathrm{AD}$ involving $\mathrm{A} \beta$-induced alterations in the alternative splicing of protein tau.

Morphologically, reports of $A \beta$ effects on neuronal cells have included the formation of autophagic vacuoles, intracellular aggregates of $\mathrm{A} \beta$ (Pajak et al. 2009), and cytoskeleton alterations by accumulation of soluble amyloid- $\beta$ precursor protein (sA $\beta$ PP) (Henriques et al. 2010). Neurite retraction in PC12 cells has been associated with 
the inhibition of tau expression (Hanemaaijer and Ginzburg 1991) and phosphorylation during programmed cell death (Nuydens et al. 1997). Although the purpose of this study was not to quantify expression levels of the amplified fragments, we show the relative gene expression, we observed that $A \beta_{42}$ exposure appears to decrease expression and mostly promotes exclusion of tau exons 2 and 3 in undifferentiated as well as NGFinduced cells, while exon 6 expression may be affected only in undifferentiated cells. The study about splicing of exons 2 and 3 is involved, when exposed to amyloid peptide has been little studied in relation to Alzheimer's disease. Most studies are directed at exon 10, and it would be interesting to further investigate these exons and how they might contribute to the generation of Alzheimer's disease.

\section{ACKNOWLEDGMENTS}

Special thanks to Dr. Beatríz Palmeros from the Faculty of Biology, UV, for allowing the use of her laboratory. The authors would like to thank the Consejo Nacional de Ciencia y Tecnología (CONACyT, Mexico) for providing funding for this study through the agreement \#106531, granted to the Cuerpo Académico de Neuroquímica (UV-CA-137). Teresa Lagunes performed the experimental work and contributed to interpretation of results. Marisol Herrera-Rivero prepared the manuscript and figures and contributed to the expression data analysis and interpretation of results. María Elena Hernández-Aguilar approved the protocol and final version of the manuscript. Gonzalo Emiliano Aranda-Abreu designed the experiments, contributed to interpretation of results and approved the final version of the manuscript.

ABBREVIATIONS - AD: Alzheimer's disease; MAPT: microtubule-associated protein tau; CT: carboxy-terminus; NT: amino-terminus; NFTs: neurofibrillary tangles; 3/4R-tau: 3/4 microtubulebinding repeats tau isoform; $A \beta$ : beta-amyloid peptide; NGF: nerve-growth factor; RT-PCR: retro- transcription polymerase-chain-reaction; cDNA: complementary deoxyribonucleic acid; mRNA: messenger ribonucleic acid; GSK-3 $\beta$ : glycogen synthase kinase 3-beta; PKA-C $\alpha$ : cyclic adenosinemonophosphate (AMP)-dependent protein kinase catalytic subunit alpha; SC35: serine/arginine rich splicing factor 2, splicing component $35 \mathrm{kDa}$; Dyrk1A: dual-specificity tyrosine phosphorylationregulated kinase 1A; 9G8: serine/arginine rich factor 9G8; SRSF1: serine/arginine rich splicing factor 1; sAPP: soluble amyloid precursor protein. No conflict of interests exists.

\section{RESUMO}

Proteína Tau desempenha um papel crucial na fisiopatologia da doença de Alzheimer, onde sua hiper-fosforilação promove agregação e desestabilização de microtúbulo. Tau submete-se a splicing alternativo que gera seis isoformas no cérebro humano, devido a inclusão/exclusão dos exons 2, 3 e 10. A desregulação do processo de splicing do exon tau 10 é suficiente para causar Taupatia e mostrou-se ser influenciado por peptídeos beta-amilóides, entretanto o splicing de outros exons é menos estudado. Nós estudamos os efeitos da betaamiloide(42) no splicing alternativo de exons tau $2 / 3$ e 6 , usando células PC12 não tratadas ou estimuladas pelo fator de crescimento do nervo. A exposição de beta-amilóide levou processos celulares formados a retrair em células diferenciadas e alterou a expressão de exons 2/3 tanto em células indiferenciadas como diferenciadas. A expressão do exon 6 foi reprimida apenas em células indiferenciadas. Nossos resultados sugerem que beta-amilóide interfere com o processo de splicing de exons $2 / 3$, favorecendo a sua exclusão e, portanto, a expressão de isoformas imaturas de tau que são menos eficientes em estabilizar microtúbulos e também podem ser mais propensas a hiperfosforilação. O mecanismo molecular para essa interação amilóide-tau permanece a ser determinado, mas pode ter implicações potenciais para a compreensão dos processos neuropatológicos fundamentais na doença de Alzheimer.

Palavras-chave: Doença de Alzheimer, peptídeo amilóide, regulação de splicing, isoformas tau. 


\section{REFERENCES}

ANDREADIS A, BRown WM AND KosIK KS. 1992. Structure and novel exons of the human tau gene. Biochemistry 31 : 10626-10633.

Arikan MC, MEMmott J, BRoderick JA, LAFyatis R, SCREATON G, STAMM S AND ANDREADIS A. 2002. Modulation of the membrane-binding projection domain of tau protein: splicing regulation of exon 3. Brain Res Mol Brain Res 101: 109-121.

BRANDT R, LÉGER J AND LEE G. 1995. Interaction of tau with the neural plasma membrane mediated by tau's aminoterminal projection domain. J Cell Biol 131: 1327-1340.

CHen KL, Yuan RY, Hu CJ AND Hsu CY. 2010. Amyloid- $\beta$ peptide alteration of tau exon-10 splicing via the GSK3 $\beta$ SC35 pathway. Neurobiol Dis 40: 378-385.

Collet J, Fehrat L, Pollard H, Ribas de Pouplana L, Charton G, Bernard A, Moreau J, Ben-ARi Y AND KHRESTCHATISKY M. 1997. Developmentally regulated alternative splicing of mRNAs encoding N-terminal tau variants in the rat hippocampus: structural and functional implications. Eur J Neurosci 9: 2723-2733.

Ding S, SHI J, QIAN W, IQBAL K, GRUNDKE-IQBAL I, GONG CX AND LIU F. 2012. Regulation of alternative splicing of tau exon 10 by 9 G8 and Dyrk1A. Neurobiol Aging 33: 1389-1399.

D'SOUZA I AND SchellenBerG GD. 2005. Regulation of tau isoform expression and dementia. Biochim Biophys Acta 1739: 104-115.

GOEDERT M AND JAKES R. 1990. Expression of separate isoforms of human tau protein: correlation with the tau pattern in brain and effects on tubulin polymerization. EMBO J 9: 4225-4230.

Goedert M, Spillantini MG, JAKEs R, RUtherford D AND CROWTHER RA. 1989. Multiple isoforms of human microtubule-associated protein tau: sequences and localization in neurofibrillary tangles of Alzheimer's disease. Neuron 3: 519-526.

GREENE LA AND TISCHLER AS. 1976. Establishment of a noradrenergic clonal line of rat adrenal pheochromocytoma cells which respond to nerve growth factor. Proc Natl Acad Sci USA 73: 2424-2428.

HANEMAAIJER R AND GINZBURG I. 1991. Involvement of mature tau isoforms in the stabilization of neurites in PC12 cells. J Neurosci Res 30: 163-171.

HeNriques AG, VieIRA SI, DA CRUZ E SiLVA EF AND DA CRUZ E SILVA OA. 2010. Abeta promotes Alzheimer's diseaselike cytoskeleton abnormalities with consequences to APP processing in neurons. J Neurochem 113: 761-771.
LIU F AND GONG CX. 2008. Tau exon 10 alternative splicing and tauopathies. Mol Neurodegener 3: 8.

LUO MH, LESKI ML AND ANDREADIS A. 2004. Tau isoforms which contain the domain encoded by exon 6 and their role in neurite elongation. J Cell Biochem 91: 880-895.

Nuydens R, Dispersyn G, De Jong M, Van Den Kieboom G, Borgers M AND GeERTS H. 1997. Aberrant tau phosphorylation and neurite retraction during NGF deprivation in PC12 cells. Biochem Biophys Res Commun 240: 687-691.

PAJAK B, SONGIN M, STROSZNAJDER JB, ORZECHOWSKI A AND GAJKOWSKA B. 2009. Ultrastructural evidence of amyloid beta-induced autophagy in PC12 cells. Folia Neuropathol 47: 252-258

PoOLER AM AND HANGER DP. 2010. Functional implications of the association of tau with the plasma membrane. Biochem Soc Trans 38: 1012-1015.

Qian W, Liang H, Shi J, Jin N, GRUNDKE-IQbal I, IQbal K, GONG CX AND LIU F. 2011. Regulation of the alternative splicing of tau exon 10 by SC35 and Dyrk1A. Nucleic Acids Res 39: 6161-6171.

SHI J, QIAN W, Yin X, IQBAL K, GRUNDKE-IQBAL I, GU X, DinG F, Gong CX AND LIU F. 2011. Cyclic AMP-dependent protein kinase regulates the alternative splicing of tau exon 10: a mechanism involved in tau pathology of Alzheimer disease. J Biol Chem 286: 14639-14648.

SMith CJ, ANDERTON BH, DAVIS DR AND GALlo JM. 1995. Tau isoform expression and phosphorylation state during differentiation of cultured neuronal cells. FEBS Lett 375: 243-248.

TRABZUNI D ET AL. 2012. MAPT expression and splicing is differentially regulated by brain region: relation to genotype and implication for tauopathies. Hum Mol Genet 21: 4094-4103.

VANIER MT, NEUVILle P, MiCHALIK L AND LAUNAY JF. 1998. Expression of specific tau exons in normal and tumoral pancreatic acinar cells. J Cell Sci 111: 1419-1432.

WEI ML AND ANDREADIS A. 1998. Splicing of a regulated exon reveals additional complexity in the axonal microtubuleassociated protein tau. J Neurochem 70: 1346-1356.

WEINGARTEN MD, LOCKWOOD AH, HWO SY AND KIRSCHNER MW. 1975. A protein factor essential for microtubule assembly. Proc Natl Acad Sci USA 72: 1858-1862. 